\title{
Indium In 111-FPI-1547
}

National Cancer Institute

\section{Source}

National Cancer Institute. Indium In 111-FPI-1547. NCI Thesaurus. Code C158816.

A radioimmunoconjug ate composed of FPI-1175 (AVE1642), a humanized monoclonal antibody against insulin-like growth factor-1 receptor (IGF-1R) linked, via the bifunctional chelate FPI-1397, to the radioisotope indium-111 (111/n or In-111), with potential imaging activity upon single photon emission computed tomography (SPECT). Upon administration of indium In 111-FPI-1547, the FPI-1547 moiety targ ets and binds to IGF1R expressed on tumor cells. Upon uptake and imaging, IGF-1R-expressing tumor cells can be visualized. This allows assessment of IGF-1R expression on tumor cells as well as tumor uptake of the agent. The linker promotes increased clearance of the radioisotope. 